\title{
EXPERIMENTS ON THE USE OF SOME CHLORONITROBENZENE AND ORGANIC MERCURY COMPOUNDS FOR THE CONTROL OF LOW-TEMPERATURE PARASITIC FUNGI ON WINTER CEREALS
}

\author{
E. A. Jamalainen \\ Department of Plant Pathology, Agricultural Research Centre, \\ Tikkurila
}

Received September 12. 1958.

Studies have been made at the Department of Plant Pathology of the Agricultural Research Centre on the possibilities of controlling damage from parasitic fungi in dormant plants by treating stands with fungicides in the autumn, shortly before the fall of snow. The results of the experiments carried out before the winter $1955-56$ were published in 1956 as Publications of the Finnish State Agricultural Research Board No. 148 - "Overwintering of plants and experiments on the chemical control of low-temperature parasitic fungi in Finland" (cf. 3, 6).

The following gives an account of the results of experiments on winter cereals carried out in $1955-1958$.

The weather conditions during the winters 1955-1958

The winter of $1955-56$ was very snowy. In south Uusimaa (central part of South Finland), where most of the experiments were carried out, there were exceptionally heavy injuries from parasitic fungi on winter cereals. The damage from snow mould [Fusarium nivale (Fr.) Ces.] in particular was heavy, but the Typhula fungi, $T$. itoana Imai and $T$. idahoensis Remsb., also proved injurious. According to information collected by the Department of Plant Pathology, injuries from fungi were also heavy in the central, eastern and northern parts of Finland. In South-West Finland the damage appeared to be comparatively slight, as usual. 
The overwintering conditions for crops in the winter 1956-57 were very different from those of the previous winter (4). The soil had frozen in late autumn before the snow fell; in South Finland the soil was depht frozen. Later in the winter the weather was so warm that rain fell, covering the fields with water. The surface of the soil became waterlogged, and the frost that followed froze the water often forming a continuous surface of ice. In 1956-57 there appeared hardly any injuries from low-temperature parasitic fungi in the winter cereals in the southern part of the country. Damage from low-temperature parasitic fungi appeared in the central and northern parts of the country, although to a lesser extent than usual owing to the fact that the soil had been throughly frozen by the time the snow fell.

Compared to the two preceding years the winter $1957-58$ was, in Finnish weather conditions, normal for the overwintering of winter cereals. The ground was almost everywhere frozen before snowfall. Snow fell comparatively abundantly, remaining on the ground all the winter through. Damage caused by water and frost did not appear in the winter cereals to any notable degree. On the other hand lowtemperature parasitic fungi (Fusarium nivale on winter rye and both $F$. nivale and Typhula sp. fungi on winter wheat) had caused considerable damage in snowy places ewerywhere in the country.

\section{Experiments with winter cereals}

Earlier experiments carried out in different countries on the chemical control of low-temperature parasitic fungi in winter cereals by a treatment of seedlings in autumn have been more detailed reported in a publication of the author in 1956 (3, p. 18-19). As to the latest studies in this field reference is made to SpRAGUE's experiments (9) in the State of Washington, U.S.A.; these did not lead to any positive results in the control of low-temperature parasitic fungi in winter wheat in 1955-1956. Regarding the experiments in the following year, SPRAGUE reports that positive results were obtained by using organic mercury compounds $(10$; $\mathrm{cp}$. also 8). - In the mountainous regions of West Germany good results have been obtained in the control of snow mould (Fusarium nivale) in winter rye by the use of the spray Brassicol-super, a PCNB preparation $(7,11)$.

\section{Chemicals used in the tests}

\begin{tabular}{|c|c|c|c|c|c|}
\hline \multirow[t]{2}{*}{ Preparation } & \multirow[t]{2}{*}{$\begin{array}{c}\text { Active } \\
\text { ingredient }\end{array}$} & \multirow[t]{2}{*}{$\begin{array}{l}\text { Appli- } \\
\text { cation ' }\end{array}$} & \multicolumn{2}{|c|}{$\begin{array}{c}\text { Amount per hectare } \\
\text { of }\end{array}$} & \multirow[t]{2}{*}{ Manufacturer } \\
\hline & & & $\begin{array}{l}\text { prepa- } \\
\text { ration }\end{array}$ & $\begin{array}{c}\text { active } \\
\text { ingredient }\end{array}$ & \\
\hline $\begin{array}{l}\text { A m a tin- } \\
S t a \text { a b }\end{array}$ & $\begin{array}{l}\text { HCNB-hexachloro- } \\
\text { nitrobenzene, } 20 \%\end{array}$ & dust & $25 \mathrm{~kg}$ & $5 \mathrm{~kg}$ & $\begin{array}{l}\text { Farbenfabriken } \\
\text { Bayer, West Germany }\end{array}$ \\
\hline A v i col & $\begin{array}{l}\mathrm{PCNB}=\text { pentachloro- } \\
\text { nitrobenzene, } 20 \%\end{array}$ & dust & $\begin{array}{ll}25 & \mathrm{~kg} \\
50 & \mathrm{~kg}\end{array}$ & $\begin{array}{r}5 \mathrm{~kg} \\
10 \mathrm{~kg}\end{array}$ & $\begin{array}{l}\text { Rikkihappo- ja super- } \\
\text { fosfaattitehtaat Oy, } \\
\text { Vaasa, Finland }\end{array}$ \\
\hline
\end{tabular}




\begin{tabular}{|c|c|c|c|c|c|}
\hline Preparation & $\begin{array}{c}\text { Active } \\
\text { ingredient }\end{array}$ & $\begin{array}{l}\text { Appli- } \\
\text { cation } 1\end{array}$ & $\begin{array}{l}\text { Amount } \\
\text { prepa- } \\
\text { ration }\end{array}$ & $\begin{array}{l}\text { per hectare } \\
\text { of } \\
\text { active } \\
\text { ingredient }\end{array}$ & Manufacturer \\
\hline B a y e r 4426 & $\begin{array}{l}\text { PMA = phenylmercury- } \\
\text { acetate, } 0.5 \% \\
(\mathrm{Hg} 0.3 \%)\end{array}$ & dust & $25 \mathrm{~kg}$ & $\begin{array}{c}125 \mathrm{~g} \\
(\mathrm{Hg} \quad 75 \mathrm{~g})\end{array}$ & $\begin{array}{l}\text { Farbenfabriken } \\
\text { Bayer, West Germany }\end{array}$ \\
\hline Botrile $x$ & $\begin{array}{l}\mathrm{PCNB}=\text { pentachloro- } \\
\text { nitrobenzene, } 20 \%\end{array}$ & dust & $\begin{array}{ll}25 & \mathrm{~kg} \\
50 & \mathrm{~kg}\end{array}$ & $\begin{aligned} 5 \mathrm{~kg} \\
10 \mathrm{~kg}\end{aligned}$ & $\begin{array}{l}\text { Bayer Agriculture } \\
\text { Ltd., England }\end{array}$ \\
\hline Brassicol & $\begin{array}{l}\mathrm{PCNB}=\text { pentachloro- } \\
\text { nitrobenzene, } 20 \%\end{array}$ & dust & $\begin{array}{ll}25 & \mathrm{~kg} \\
50 & \mathrm{~kg}\end{array}$ & $\begin{array}{r}5 \mathrm{~kg} \\
10 \mathrm{~kg}\end{array}$ & $\begin{array}{l}\text { Hoechst A.-G., } \\
\text { West Germany }\end{array}$ \\
\hline Dith a n e $Z-78$ & Zineb, $65 \%$ & dust & $25 \mathrm{~kg}$ & $16.25 \mathrm{~kg}$ & $\begin{array}{l}\text { Rohm \& Haas Co, } \\
\text { Philadelphia, U.S.A. }\end{array}$ \\
\hline Fernasan 75 & Thiram, $75 \%$ & $\begin{array}{l}\text { seed } \\
\text { dressing }\end{array}$ & $\begin{array}{l}\text { about } \\
0.5 \mathrm{~kg}\end{array}$ & $375 \mathrm{~g}$ & $\begin{array}{l}\text { Plant Protection } \\
\text { Ltd., England }\end{array}$ \\
\hline Mercad m ine & $\begin{array}{l}\text { PMS }=\text { phenylmercury- } \\
\text { salicylate, } 5 \% \\
(\mathrm{Hg} 2.35 \% \text { ) and } \\
\text { cadmium ricinoleate }\end{array}$ & spray & $4.7 \mathrm{~kg}$ & $\begin{array}{c}235 \\
\mathrm{Hg} \quad 110.5\end{array}$ & $\begin{array}{l}\text { H. L. Woudhuysen } \\
\text { Ltd., New York, } \\
\text { U.S.A. }\end{array}$ \\
\hline Merculine & $\begin{array}{l}\text { PMS = phenylmercury- } \\
\text { salicylate, } 10 \% \\
(\text { Hg } 4.7 \%)\end{array}$ & spray & $4.7 \mathrm{~kg}$ & $\begin{array}{c}470 \mathrm{~g} \\
(\mathrm{Hg} 221 \mathrm{~g})\end{array}$ & $\begin{array}{l}\text { H. L. Woudhuysen } \\
\text { Ltd., New York, } \\
\text { U.S.A. }\end{array}$ \\
\hline T äyssato & $\begin{array}{l}\text { metoxethylmercury- } \\
\text { chloride, } 2.2 \% \\
(\mathrm{Hg} \quad 1.5 \% \text { ) }\end{array}$ & $\begin{array}{l}\text { seed } \\
\text { dressing }\end{array}$ & $\begin{array}{l}\text { about } \\
0.5 \mathrm{~kg}\end{array}$ & $\begin{array}{c}11.0 \mathrm{~g} \\
(\mathrm{Hg} 7.5 \mathrm{~g})\end{array}$ & $\begin{array}{l}\text { Rikkihappo- ja super- } \\
\text { fosfaattitehtaat Oy., } \\
\text { Vaasa, Finland }\end{array}$ \\
\hline Verdas a n & $\begin{array}{l}\text { PMA = phenylmercury- } \\
\text { acetate, } 5 \% \\
(\mathrm{Hg} 2.5 \%)\end{array}$ & $\begin{array}{l}\text { dust or } \\
\text { spray }\end{array}$ & $8.5 \mathrm{~kg}$ & $\begin{array}{c}425 \mathrm{~g} \\
(\mathrm{Hg} 212.5 \mathrm{~g})\end{array}$ & $\begin{array}{l}\text { Plant Protection } \\
\text { Ltd., England }\end{array}$ \\
\hline Us no & Usnic acid & spray & & $86 \mathrm{~g}$ & Lääke Oy., Finland \\
\hline
\end{tabular}

1 By spraying $700-8001$ water pro hectare; Verdasan mixed with fine sand before dusting.

Tests with winter rye. In the tests carried out with winter rye at the Department of Plant Pathology at Tikkurila (near Helsinki), in which a PCNB preparation was used for the first time in the autumn of 1945 , it was ascertained that PCNB effectively reduced injuries by snow mould (Fusarium nivale) (2). In tests with winter rye in $1954-55$, a noticeable increase in the yield was obtained by the use of both PCNB and PMA (Verdasan) preparations (6).

The fungicide treatment tests with seedlings of winter rye were continued during the autumn of 1955 on the fields belonging to the Department of Plant 
Pathology at Tikkurila and Rekola (near Helsinki), as well as on the Fiskars estate (Pohja commune) in the western part of South Finland.

In the tests at Tikkurila with Visa rye variety (Table 1, Exp. I), according to observations made in the spring, snow mould (Fusarium nivale) was the sole cause of overwintering injuries. The PMA and PCNB preparations gave the best results in the control of Fusarium mould; the effect of the zineb preparations was slight.

In the tests with Pekka rye variety at Rekola (Table 1, Exp. II), the stands treated with PMS preparations overwintered without injuries from fungi. On the other hand, the untreated plots were heavily attacked by Fusarium mould, and Typhula mould was also present.

In tests on observation plots at Fekola (Table 1, Exp. III) a late application of the PCNB preparation (on Nov. 14th) seemed to produce the best results; the results corresponded to those of earlier experiences $(6)$.

Table 1. Experiments in treating seedlings of winter rye in $1955-56$. Seed dressed with organic mercury seed disinfectant. In autumn the sprouting in all plots normal and even.

Treatment

\begin{tabular}{cccc}
\multicolumn{2}{c}{ On the seedlings } & \multicolumn{2}{c}{ Seed yield } \\
May 16 & $\mathrm{~kg} / \mathrm{ha}$ & $\mathrm{rel}$ \\
Fusarium & Typhula & & \\
mould $\%$ & mould $\%$ & &
\end{tabular}

I T i k k u ril a, finesand clay, Visa rye variety, plots 20 sq.m., 5 replicates, sown Sept. 6, chemicals spread Nov. 14-16.

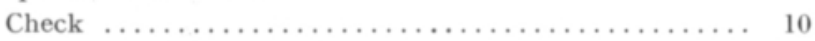

PCNB, Botrilex, $25 \mathrm{~kg} / \mathrm{ha}$, dust $\ldots \ldots \ldots \ldots \ldots \ldots \ldots \ldots$

PMA, Verdasan, $8.5 \mathrm{~kg} / \mathrm{ha}$, spray $\ldots \ldots \ldots \ldots \ldots \ldots$

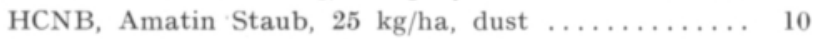

Zineb, Dithane Z-78, $25 \mathrm{~kg} / \mathrm{ha}$, dust $\ldots \ldots \ldots \ldots \ldots$

F-value $=3.025^{*}, \mathrm{~m} \%=4.9$, significant difference $=415 \mathrm{~kg}$

$\begin{array}{lll}0 & 2450 & 100 \\ 0 & 2990 & 122 \\ 0 & 3080 & 126 \\ 0 & 2840 & 116 \\ 0 & 2600 & 106\end{array}$

II R e k o l a, Helsinki community, mould soil, Pekka rye variety, plots 20 sq.m., 3 replicates, sowing Sept. 9, chemicals spread on Nov. 16.

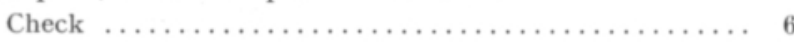

PMS, Mercadmine, $4.7 \mathrm{~kg} / \mathrm{ha}$, spray $\ldots \ldots \ldots \ldots \ldots . \ldots$

PMS, Merculine, $4.7 \mathrm{~kg} / \mathrm{ha}$, spray $\ldots \ldots \ldots \ldots \ldots \ldots$

$\begin{array}{rrrr}60 & 20 & 1260 & 100 \\ 0 & 0 & 2360 & 187 \\ 0 & 0 & 2780 & 220 \\ 5 & + & 2040 & 162\end{array}$

PCNB, Avicol, $25 \mathrm{~kg} / \mathrm{ha}$, dust ............... $5 . \ldots 2040 \quad 262$

F-value $=70.065^{* * *}, \mathrm{~m} \%=2.79$, significant difference $=356 \mathrm{~kg}$

III R e k o la, observation plots on mould soil, Pekka rye variety, plots 14.5 sq.m., one replicate, sown Sept. 5, treatment with PCNB preparation Botrilex $25 \mathrm{~kg} / \mathrm{ha}$ used at each dusting.

\begin{tabular}{|c|c|c|c|c|c|c|}
\hline Check & . & $\cdots$ & 70 & 10 & 1350 & 100 \\
\hline PCNB & treatment & Oct. $10 \ldots \ldots \ldots \ldots \ldots \ldots \ldots \ldots$ & 40 & 30 & 1300 & 96 \\
\hline , & , & Nov. $3 \ldots \ldots \ldots \ldots \ldots \ldots \ldots \ldots$ & 40 & 25 & 1410 & 104 \\
\hline , & , & $\ldots \ldots \ldots \ldots \ldots \ldots \ldots \ldots \ldots$ & 20 & 20 & 1680 & 124 \\
\hline , & , & Oct. 27 and Nov. $3 \ldots \ldots \ldots$ & 35 & 25 & 1895 & 140 \\
\hline , & , & Oct. 27, Nov. 3 and Nov. $14 \ldots \ldots$ & 20 & 20 & 2070 & 153 \\
\hline
\end{tabular}


Of the two tests made on the Fiskars estate, the results of which are not presented, the PCNB preparation increased the seed yield by $39 \%$ in one test with Visa rye variety. In the other test the treatment with PCNB did not improve the yield.

In the seed dressing experiments with winter rye carried out in $1955-56$ the increase in yields due to the seed dressing was very considerable (Table 2). The organic mercury preparation Täyssato increased the yield by 140 per cent, the

Table 2. Experiment in dressing seed of winter rye in 1955-56, Tikkurila. Finesand clay, Visa rye variety, plots 19 sq.m., 4 replicates, sowing in Sept. 5. In autumn the sprouting in all plots normal and even.

\begin{tabular}{|c|c|c|c|c|c|}
\hline Treatment & \multicolumn{2}{|c|}{$\begin{array}{c}\text { Seed before } \\
\text { the sowing } \\
\text { germinating mould }\end{array}$} & $\begin{array}{c}\text { On the seedlings } \\
\text { May } 5 \\
\text { Fusarium mould } \\
\%\end{array}$ & Seed & rield \\
\hline$\ldots \ldots \ldots \ldots \ldots \ldots \ldots \ldots \ldots \ldots$ & 89 & 1 & 50 & 850 & 100 \\
\hline $\begin{array}{l}\text { Org. mercury seed disinfectant, Täyssato, } \\
2 \mathrm{~kg} / \mathbf{l} \mathrm{kg} \ldots \ldots \ldots \ldots \ldots \ldots \ldots \ldots \ldots \ldots \ldots \ldots \ldots \ldots\end{array}$ & 88 & 0 & 10 & 2040 & 240 \\
\hline Thiram, Fernasan $75,2 \mathrm{~kg} / 1 \mathrm{~kg} \ldots \ldots \ldots$. & $\begin{array}{l}89 \\
\text {. } 89\end{array}$ & 0 & 20 & 1950 & 229 \\
\hline $\begin{array}{r}\text { Tãyssato, } 2 \mathrm{~g} / 1 \mathrm{~kg}+\text { Fernasan } 75,2 \mathrm{~g} / \mathrm{kg} \ldots \\
\text { F-value } 2.707, \mathrm{~m} \%=11.7 \text {, significan }\end{array}$ & $\begin{array}{c}86 \\
\text { nt diffe }\end{array}$ & $\begin{array}{l}0 \\
=6\end{array}$ & $72 \mathrm{~kg}$ & 2250 & 265 \\
\hline
\end{tabular}

thiram preparation (Fernasan 75) by 129 per cent, and both these preparations used together in seed dressing increased the yield by 165 per cent. It should be noted that mould had not been found on the seed while it was germinating in the laboratory.

In tests with winter rye in South Finland in 1956-57, treatment of the seedlings with fungicides in the autumn did not lead to any increase in the yield, as injuries from low-temperature parasitic fungi did not make their appearance. On the other hand, low-temperature parasitic fungi were found in tests with winter rye made

Table 3. Observations of low-temperature parasitic fungi in experiments on winter rye in $1956-57$. In autumn the sprouting in all plots normal and even.

$\begin{array}{cccc} & \text { Seedlings } & \text { On the seedlings } \\ \text { Testroyed } & \text { May } 20 \\ & \text { during winter } & \text { Fusarium } & \text { Typhula } \\ & \% & \text { mould } \% & \text { mould } \%\end{array}$

A p u k k a, Polar Circle Exp. Sta., Rovaniemi, finesand clay, Greus rye variety, the seed dressed with organic mercury disinfectant, chemicals spread Oct. 22 on the snow.

Check $\ldots \ldots \ldots \ldots \ldots \ldots \ldots \ldots \ldots \ldots \ldots \ldots \ldots \ldots \ldots \ldots \ldots \ldots \ldots \ldots \ldots \ldots$
PCNB, Avicol Oct. 5, and Oct. 22, dusting with $25 \mathrm{~kg} / \mathrm{ha} \ldots$
PCNB, Avicol, Oct. $22,25 \mathrm{~kg} /$ ha dust $\ldots \ldots \ldots \ldots \ldots \ldots$


Seedlings

Rye varieties destroyd

during winter \%

check
On the seedlings

May 16

Fusarium mould \% ${ }^{2}$ )

M a a $\mathrm{n}$ i n k a, Pohjois-Savo Exp. Sta., mould soil, PCNB (Avicol), spread as dust $25 \mathrm{~kg} / \mathrm{ha}$ on Oct. 30 , seed dressed with organic mercury disinfectant.

\begin{tabular}{|c|c|c|c|c|}
\hline 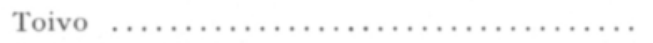 & 50 & 2 & 50 & + \\
\hline Toivo, seed not dressed $\ldots \ldots \ldots \ldots \ldots \ldots \ldots$ & 50 & 5 & 50 & 5.5 \\
\hline Pekka $\ldots \ldots \ldots \ldots \ldots \ldots \ldots \ldots \ldots \ldots \ldots \ldots \ldots \ldots \ldots \ldots \ldots \ldots \ldots$ & 40 & 10 & 30 & + \\
\hline 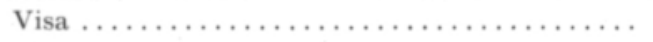 & 35 & 10 & 30 & + \\
\hline 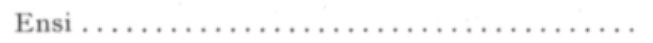 & 10 & $20^{1}$ & + & 0 \\
\hline Vjatka $\quad \ldots \ldots \ldots \ldots \ldots \ldots \ldots \ldots \ldots \ldots \ldots \ldots \ldots \ldots \ldots \ldots \ldots$ & 2 & 2 & 0 & 0 \\
\hline Vjatka, seed not dressed $\ldots \ldots \ldots \ldots \ldots \ldots$ & 15 & $30^{1}$ & 0 & 0 \\
\hline Halola $\ldots \ldots \ldots \ldots \ldots \ldots \ldots \ldots \ldots \ldots \ldots \ldots \ldots \ldots \ldots \ldots$ & 10 & $30^{1}$ & 0 & 0 \\
\hline 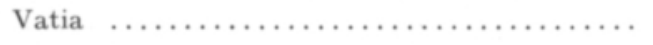 & 5 & 2 & 0 & 0 \\
\hline
\end{tabular}

at the Polar Circle Experiment Station at Apukka (near Rovaniemi) and at the North Savo Experiment Station at Maaninka (in the eastern part of Central Finland). In analyses carried out at the Polar Circle Exp. Sta. in the spring, a distinct difference with regard to the amount of Fusarium mould and Typhula mould was established between the check plots and the plots treated with PCNB (Table 3). - In tests with winter rye varieties at the North Savo Experiment Station, differences with regard to the amount of Fusarium mould were found between the different varieties and also between the check plots and the plots treated with PCNB (Table 3). Fusarium mould appeared in abundance in the Toivo, Pekka and Visa rye varieties; treatment with PCNB during the autumn had proved very effective against this.

In the experiments with winter rye carried out at Tikkurila in $1957-58$ (Table 4) the cause of damage during the winter was Fusarium nivale. In a treatment time test it was found that treatment with both PCNB and PMA carried out in November gave better results than similar treatment in October (Table 4, Exp. I). In the other experiment with winter rye PMA and PMS (Mercadmine) were effective against Fusarium mould as shown in Table 4, Exp. II. The usnic acid preparation Usno had also reduced the Fusarium mould (Table 4, Exp. II).

Tests with winter wheat. In a test with winter wheat at Tikkurila in $1954-55$, treatment with PCNB did not improve the yield (6). The dusting was carried out on Oct. 5th, using $25 \mathrm{~kg}$ of PCNB preparation per hectare.

In tests with winter wheat on sandy soil carried out at Tikkurila in the autumn of 1955 (Table 5, Exp. I), both PCNB and PMA preparations effectively reduced injuries from Fusarium mould, which resulted in considerable increases in yield. The PCNB preparation was effective against the Typhula fungi, a double dosage, 
Table 4. Experiments on winter rye in 1957-1958, Tikkurila. In autumn the sprouting in all plots normal and even.

\begin{tabular}{lccccc}
\hline & $\begin{array}{c}\text { On the seedling } \\
\text { May } 19 \\
\text { Treatment }\end{array}$ & Seed yield & Stalk yield \\
& Fusarium mould $\%$ & $\mathrm{~kg} / \mathrm{ha} \quad \mathrm{rel}$. & $\mathrm{kg} / \mathrm{ha}$ & rel. \\
\hline
\end{tabular}

I. Tikkurila, finesand clay, Tetra rye variety, plots 19.8 sq.m., 5 replicates, sowing Sept. 5 with undressed seed; chemicals applied by dusting, Verdasan mixed in sand.

$\begin{array}{lrrrrrr}\text { Check } \ldots \ldots \ldots \ldots \ldots \ldots \ldots \ldots \ldots & 39 & 1175 & 100 & 3220 & 100 \\ \text { PCBN, Botrilex, Oct. 15, 25 kg/ha .. } & 38 & 1310 & 111 & 3380 & 105 \\ \text { PCNB, Botrilex, Nov. 12, 25 kg/ha .. } & 17 & 1390 & 118 & 3620 & 112 \\ \text { PMA, Verdasan, Oct. 15, 25 kg/ha .. } & 8 & 1620 & 138 & 4240 & 132 \\ \text { PMA, Verdasan, Nov. 12, } 25 \mathrm{~kg} / \mathrm{ha} \ldots & 3 & 1700 & 145 & 4250 & 132\end{array}$

F-value $=5.1^{\text {** }} \mathrm{m} \%=17.3$, significant difference $=2.1 \mathrm{~kg}$.

II. Tikkurila, observation plots on finesand clay, Visa rye variety, plots 18 sq.m., one replicate, sowing Sept. 5 with undressed seed, treatment of seedlings Nov. 12.

\begin{tabular}{|c|c|c|c|c|c|}
\hline Check $\ldots \ldots \ldots \ldots \ldots \ldots \ldots \ldots \ldots \ldots \ldots \ldots$ & 35 & 1030 & 100 & 2470 & 100 \\
\hline PMA, Bayer $4426,25 \mathrm{~kg} / \mathrm{ha}$, dust $\ldots$. & 1 & 2720 & 264 & 6580 & 266 \\
\hline $\begin{array}{l}\text { PMA, Verdasan, } 8.5 \mathrm{~kg} / \mathrm{ha} \text {, dust mixed } \\
\text { with sand } \ldots \ldots \ldots \ldots \ldots \ldots \ldots \ldots \ldots \ldots\end{array}$ & 0 & 2270 & 220 & 5450 & 221 \\
\hline PMS, Mercadmine, $4.7 \mathrm{~kg} / \mathrm{ha}$, spray .. & 0 & 2160 & 210 & 5070 & 205 \\
\hline Usno, $86 \mathrm{~g} / \mathrm{ha}$, spray $\ldots \ldots \ldots \ldots \ldots$ & 15 & 1540 & 150 & 3790 & 153 \\
\hline
\end{tabular}

$50 \mathrm{~kg} / \mathrm{ha}$, having a greater effect than $25 \mathrm{~kg} / \mathrm{ha}$. On finesand clay soil (Table 5, Exp. II) the PMA preparation effectively reduced injuries by Fusarium mould, and a particularly large increase in yield was obtained from the test plots treated with this preparation. The effects of $\mathrm{PCNB}, \mathrm{HCNB}$ and ineb preparations were slighter. - In tests carried out on sandy soil on the Anttila experiment farm at Tuusula (Table 5, Exp. III) the overwintering of wheat was particularly poor, owing to Fusarium mould. PCNB treatment $(25 \mathrm{~kg} / \mathrm{ha})$ had improved the yield fourfold, though it still remained low.

In $1956-57$, as there were no noteworthy injuries from low-temperature parasitic fungi in South Finland, no indications of control by either PCNB or organic mercury preparations were noted in the tests with winter wheat.

In an experiment with winter wheat sown on sandy soil in $1957-58$ there appeared much damage from low-temperature fungi (Table 6, fig. 1) in spring. The damage was caused by the Typhula fungi, mainly by $T$. idahoensis; $T$. itoana was found to be rather scarce. In contrast with the spring of 1956 there appeared very little Fusarium nivale on the winter wheat. The experiment showed that a treatment with PCNB as well as with PMA preparations carried out late in November was noticeably distinctly more effective than one performed in October. PCNB and PMA if used together controlled almost totally the damage from lowtemperature fungi. The PMA preparation Bayer 4426 was more effective than the 
Table 5. Experiments on winter wheat in $1955-56$. In autumn the sprouting normal and even.

$$
+=\text { traces of mould }
$$

\begin{tabular}{|c|c|c|c|c|}
\hline \multirow[b]{2}{*}{ Treatment } & \multicolumn{2}{|c|}{$\begin{array}{l}\text { On the seedlings } \\
\text { May } 16\end{array}$} & \multicolumn{2}{|c|}{ Seed yield } \\
\hline & $\begin{array}{c}\text { Fusarium } \\
\text { mould } \\
\%\end{array}$ & $\begin{array}{c}\text { Typhula } \\
\text { mould } \\
\%\end{array}$ & $\mathrm{~kg} / \mathrm{ha}$ & rel. \\
\hline
\end{tabular}

I. T i k k u rila, sandy soil, Ertus wheat variety, plots 9 sq.m., 4 replicates, sown Sept. 5 with undressed seed, chemicals spread by dusting Nov. 14.

\begin{tabular}{|c|c|c|c|c|}
\hline $\begin{array}{l}\text { Check } \ldots \ldots \ldots \ldots \ldots \ldots \ldots \ldots \ldots \ldots \ldots \\
\text { Seed dressed with org. mercury preparation }\end{array}$ & 50 & 20 & 1530 & 100 \\
\hline Täyssato, $2 \mathrm{~g} / \mathrm{l} \mathrm{kg} \ldots \ldots \ldots \ldots \ldots \ldots$ & 45 & 25 & 1830 & 119 \\
\hline PCNB, Botrilex, $25 \mathrm{~kg} / \mathrm{ha}$, dust $\ldots \ldots \ldots \ldots$ & 25 & 10 & 2840 & 186 \\
\hline PCNB, Botrilex, $50 \mathrm{~kg} / \mathrm{ha}$, dust $\ldots \ldots \ldots \ldots$ & 25 & 5 & 2890 & 189 \\
\hline PMA, Bayer $4426,85 \mathrm{~kg} / \mathrm{ha}$, spray ....... & 20 & 20 & 2890 & 189 \\
\hline
\end{tabular}

$$
\text { F-value }=3.315^{* * *}, \mathrm{~m} \%=12.626 \text {, significant difference }=904 \mathrm{~kg}
$$

II. Tikkurila, finesand clay, soil, Ertus wheat variety, plots 14.5 sq.m., 5 replicates, seed dressed with organic mercury preparation, sown Sept. 6, chemicals spread by dusting Nov. 14-16.

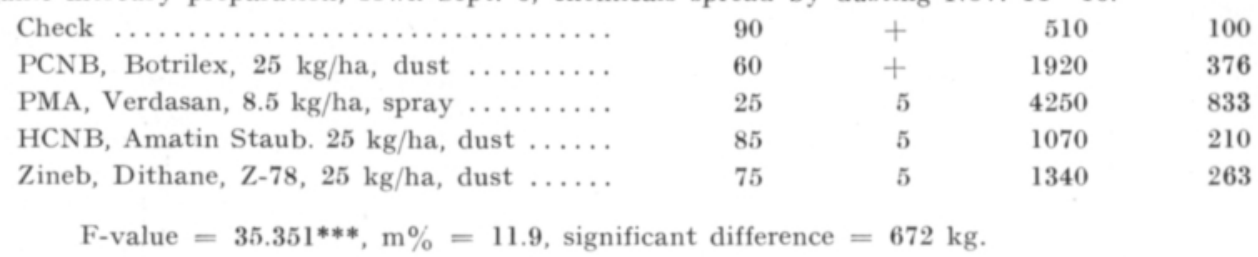

III. Anttila Exp. Farm, Tuusula, sandy soil, Antti wheat variety, seed dressed with organic mercury preparation, sown Sept. 10, chemical spread Nov. 19, damages caused by Fusarium mould during winter.

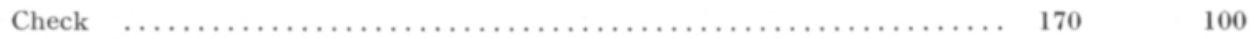

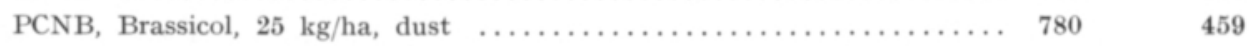

PMA preparation Verdasan (cf. the amounts of active ingredients in these preparations on page 253). The increases in yields of both grain and stalk were very considerable owing to the treatment. The increase in the yield of grain due to treatment with PCNB preparation in November was 31 per cent, with the PMA preparation Verdasan it was 30 per cent, with the PMA preparation Bayer 4426 42 per cent, and with PCNB + PMA preparations 46 per cent. Judging by the damage by low-temperature fungi showing on the seedlings in spring (Table 6) even greater increases in yield were expected, but during the period of growth the surviving seedlings tillered very richly. The results of the yield are nevertheless in direct correlation to the results obtained by analysing the seedlings in spring. 


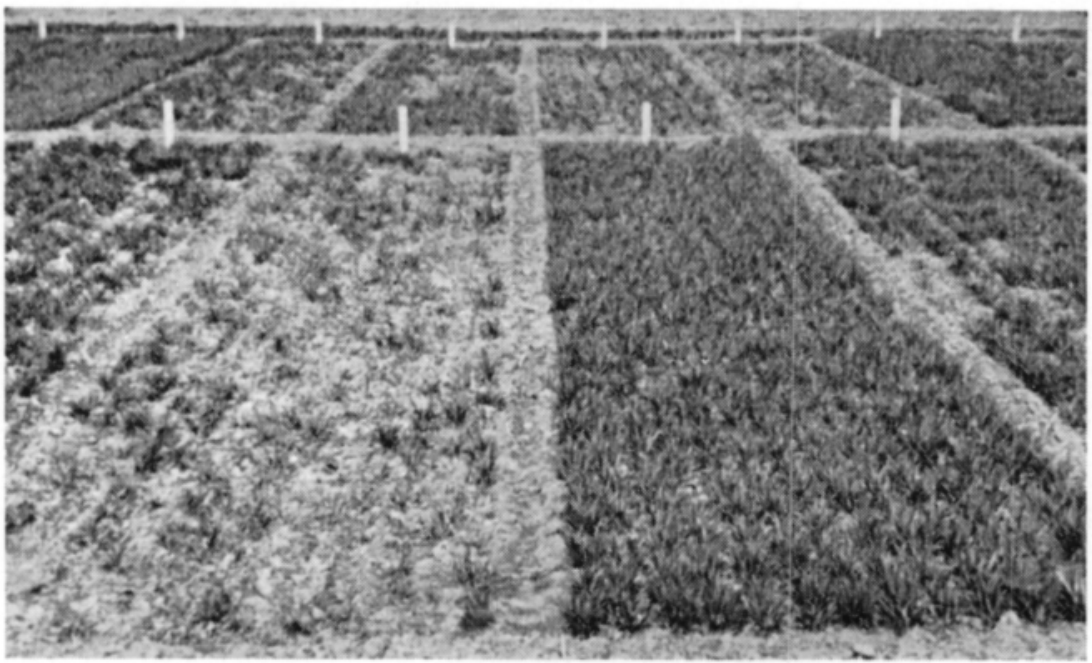

Fig. 1. An experiment at the Department of Plant Pathology in Tikkurila by Ertus winter wheat variety. To the right, plot with stands treated on Nov. 12 with the PMA preparation (Bayer 4426); to the left, untreated plot, damages caused chiefly by Typhula idahoensis. Photo taken in May. 1958.

Table 6. Experiment on winter wheat in $1957-58$, Tikkurila.

Sandy soil; Ertus wheat variety; size of plots 20 sq.m., four replicates; sown Aug. 30.

In autumn the sprouting normal and even.

\begin{tabular}{cccccc} 
& On the seedlings & \multicolumn{2}{c}{ Seed yield } & \multicolumn{2}{c}{ Straw crop } \\
May $\left.12^{1}\right)$ & & & & \\
Fusarium & Typhula & $\mathrm{kg} / \mathrm{ha}$ & $\mathrm{rel}$. & $\mathrm{kg} / \mathrm{ha}$ & $\mathrm{rel}$. \\
mould & mould & & & & \\
$\%$ & $\%$ & & & &
\end{tabular}

\begin{tabular}{|c|c|c|c|c|c|c|}
\hline Check $\ldots \ldots \ldots \ldots \ldots \ldots \ldots \ldots \ldots \ldots \ldots \ldots \ldots \ldots \ldots \ldots \ldots \ldots$ & 4.5 & 63.1 & 3125 & 100 & 3795 & 100 \\
\hline Seed dressed, Täyssato, $2 \mathrm{~g} / 1 \mathrm{~kg} \ldots \ldots \ldots$ & 2.8 & 52.2 & 3305 & 106 & 4185 & 110 \\
\hline PCNB, Botrilex, Oct. $15,25 \mathrm{~kg} / \mathrm{ha}$, dust & 2.9 & 50.6 & 3510 & 112 & 4690 & 124 \\
\hline PCNB, Botrilex, Nov. $12,25 \mathrm{~kg} / \mathrm{ha}$, dust & 0.5 & 34.9 & 3775 & 121 & 4965 & 131 \\
\hline PMA, Verdasan, Oct. $15,8.5 \mathrm{~kg} / \mathrm{ha}$, dust & 1.3 & 41.1 & 3655 & 117 & 4660 & 123 \\
\hline PMA, Verdasan, Nov. $12,8.5 \mathrm{~kg} / \mathrm{ha}$, dust & 0.7 & 13.3 & 3775 & 121 & 4950 & 130 \\
\hline $\begin{array}{l}\text { PCNB, Botrilex, } 25 \mathrm{~kg} / \mathrm{ha}+\text { PMA, Verda- } \\
\text { san, } 8.5 \mathrm{~kg} / \mathrm{ha} \text {, Nov. } 12 \text {, dust } \ldots \ldots \ldots\end{array}$ & 0 & 3.3 & 4035 & 129 & 5545 & 146 \\
\hline PMA, Bayer 4426, Nov, $12,25 \mathrm{~kg} / \mathrm{ha}$, dust & 1.1 & 21.6 & 4045 & 129 & 5395 & 142 \\
\hline
\end{tabular}

F-value $=3.79^{* * *} \mathrm{~m} \%=8.3$, significant difference $0.86 \mathrm{~kg}$.

1) Analysis made by counting the seedlings in each plot of two square metres; Typhula mould chiefly $T$, idahoensis, $T$. itoana was rather scarce. 
Experiments with winter barley. Winter barley is not grown in Finland because its overwintering is often unsuccessful. The main reason for the poor overwintering of winter barley in this country is damage caused by lowtemperature parasitic fungi and frost. The significance of low-temperature fungi is shown in an experiment carried out at Tikkurila in $1957-58$ with the Bore variety of winter barley (of Danish origin), sown Sept. 13, 1957. Two plots, both one are large, were used in the experiment, one of them untreated, the other treated with PCNB + PMA in the autumn. The seeds sprouted normally in the field in the autumn. The results of the test were as follows:

\begin{tabular}{|c|c|c|c|}
\hline \multirow[t]{2}{*}{ Treatment } & \multirow{2}{*}{$\begin{array}{c}\text { On the seedlings } \\
\text { on May } 13 \\
\text { Fusarium mould \% }\end{array}$} & \multicolumn{2}{|c|}{ Seed yield } \\
\hline & & $\mathrm{kg} / \mathrm{ha}$ & rel. \\
\hline $\begin{array}{l}\text { Check } \ldots \ldots \ldots \ldots \ldots \ldots \ldots \\
\text { Treatment in Nov. } 12 \text { : } \\
\text { PCNB, Botrilex } 50 \mathrm{~kg} / \mathrm{ha}+ \\
\text { PMA Verdasan. } 8.5 \mathrm{~kg} / \mathrm{ha}\end{array}$ & 52 & 281 & 100 \\
\hline
\end{tabular}

The yields was modest, which was probably due to frost injuries. The treatment with the PCNB + PMA preparation in the autumn had effectively controlled the injuries from Fusarium mould.

In this experiment in $1957-58$ another variety of winter barley was also used, Pioner HF (the seeds were obtained from England). This had totally disappeared during the winter, apparently because of the frost. In the autumn the seeds of this variety had sprouted normally.

\section{On the amount of fungicides effective against low-temperature fungi}

According to results of previous tests $20 \%$ PCNB preparations applied $25 \mathrm{~kg} / \mathrm{ha}$ were effective against both Fusarium mould and Typhula mould on winter cereals. However, they did not entirely control the injuries of low-temperature parasitic fungi in all the tests.

The mercury compounds PMA and PMS were in the experiments distinctly more effective against low-temperature fungi than PCNB. It should be noted that with the mercury compounds the amounts of active ingredients per hectare were very low (cf. p. 253). If the amount of $\mathrm{Hg}$ per hectare is calculated, it is in the PMA preparation Bayer 4426 only 75 grams, in the PMA preparation Verdasan 212.5, and in the PMS preparations 110.5 and 221 grams.

In this connection note should also be taken of the effect of seed dressing on the low-temperature parasitic fungi during the overwintering period. In the seed dressing experiment with winter rye in $1956-57$ (Table 2) there was no mould on the seed used in sowing. In the spring there was far less snow mould in the treated plots than in the check plots resulting in considerable increases in the yield. 
In the preceding autumn the sprouting was even in all plots. The small amount of fungicide which accompanied the seed into the field must have protected the seedlings from damage by Fusarium mould during the overwintering. With the org. mercury preparation Täyssato about $7.5 \mathrm{~g}$ of $\mathrm{Hg}$ got into the soil and with the preparation Fernasan $375 \mathrm{~g}$ of thiram. - The increases in the yields of winter cereals due to seed dressing are very considerable in Finland. In experiments made in different parts of the country during the period 1928-1950 (1) the increases in yields of winter rye due to treatment with organic mercury compounds were on an average 19.4 per cent (131 tests trials) and of winter wheat 6.1 per cent (35 tests trials). The seeds used in these tests sprouted in general normally, accordingly the increases in yield must be considered as being mainly caused by the fungicidal effect of the mercury compounds on the low-temperature fungi in the soil during overwintering (cf. 5).

\section{Sum $m$ ar $y$}

The cause of damage from low-temperature parasitic fungi during overwintering was in the experiments with winter rye mainly Fusarium nivale (Fr.) Ces., in the experiments with winter wheat both $F$. nivale and the Typhula spp. fungi, $T$. itoana Imai and $T$. idahoensis Remsb.

The pentachloronitrobenzene compounds PCNB and the organic mercury compounds phenylmercuryacetate (PMA) and phenylmercurysalicylate (PMS) were effective against both the Fusarium and the Typhula fungi in the experiments in which the treatments of the seedlings had been performed in November under weather conditions normal for South Finland. The effect of treatments performed correspondingly earlier in October was slighter.

In experiments made in South Finland in the winter 1955-56 and in the winter $1957-58$, when low-temperature parasitic fungi appeared in abundance, the increases in yield due to treatment of the seedlings with PCNB and with the mercury compounds PMA and PMS performed in November were very considerable: winter rye ( 7 tests) $12-122$ per cent, winter wheat ( 4 tests) $31-735$ per cent, and winter barley (one test) 124 per cent. - In the experiments made in 1956-57 in South Finland no increase in yield was obtained through treatment of the seedlings because low-temperature fungi did not appear.

The mercury compounds PMA and PMS when applied on the stands in autumn were more effective against low-temperature parasitic fungi on winter cereals than the PCNB preparations.

The effect of zineb and hexachloronitrobenzene (HCNB) preparations in controlling low-temperature parasitic fungi on winter cereals by treating the stands in autumn was found to be much slighter than the effect of PCNB and of the organic mercury fungicides.

The amount of active ingredient in the PCNB preparations was in most experiments $5 \mathrm{~kg}$ per hectare. In the two PMA preparations used in the experiments the amount of active ingredient was 125 and $425 \mathrm{~kg}$ per hectare, the corresponding 
amounts of $\mathrm{Hg}$ were 75 and $212.5 \mathrm{~g}$ per hectare. The amount of active ingredient in the two PMS preparations was 235 and $470 \mathrm{~g}$ per hectare, the corresponding amounts of $\mathrm{Hg}$ were 110.5 and $221 \mathrm{~g}$ per hectare.

In the experiment on seed dressing with winter rye in $1955-56$ it was ascertained that in addition to the organic mercury preparations also the thiram preparation was effective against Fusarium mould.

In seed dressing experiments in Finland considerable increases in yield especially of winter rye have been obtained by using organic mercury compounds when the seed has been normally germinating and not infested by mould. This shows that the small amount of mercury that accompanies the seed into the soil is effective in controlling the low-temperature fungi during the winter.

Acknowledgment. The author expresses his deep gratitude to Mr. MatTi HaAvisto, Plant Protection Inspector, who assisted him in carrying out the experiments reported in this paper. The valuable work of Mr. Haavisto was interrupted by his death from heart failure in February 1958. - The Department of Plant Pathology wishes to express its gratitude also to the persons who took part in organising the experiments on the Experimental Stations and on the private farms.

REFER E N E S :

(1) ElomaA, A. 1952. Viljan peittauskokeiden tuloksia vuosilta 1928-1950. Summary: Results of cereal seed treatment experiments with desinfectants during the years 1928-1950. Rep. Finnish Sta. Agric. Res. Board. 226: 1-43.

(2) JAmalainen, E. A. 1946. Maatalouskoelaitoksen kasvitautiosaston vuosikertomus. Moniste (Annual report of the Department of Plant Pathology of Agricultural Research Centre, Mimeograph). Tikkurila.

(3) —- 1956. Overwintering of plants in Finland with respect to damage caused by lowtemperature pathogens. Selostus: Kasvien talvehtimiskysymys Suomessa tuhosienien vahinkoja silmälläpitäen. Publ. Finnish Sta. Agric. Res. Board. 148: 5-30.

(4) $\longrightarrow$ 1958. Om växternas övervintring (On overwintering of plants, Swedish). Sv. lantbrukssällskap. i Finland förbund, Ser. 13, 22: 1-40. Helsinki.

$(5) \rightarrow-1958$. The effect of seed dressing of winter cereals on low-temperature parasitic fungi. J. Sci. Agric. Soc. Finland, 30: 200-201.

(6) $\rightarrow$ \& Y Y.MÄKI, A. 1956. The control of snow mould in winter rye by treatment of stands with chemicals. Selostus: Syysrukiin lumihomeen torjunta käsittelemällä oraat kemialsilla aineilla. Publ. Finnish Sta. Agric. Res. Board 148: 50-57.

(7) Pichlek, F. 1957. Uber Schneeschimmelbekämpfung. Bayerisches Landw. Jbuch, 34, Sonderheft 2: $26-29$.

(8) Sмгтн, J. D. 1957. A now fungicide formulation for Fusarium patch disease control. J. Sports Turf Res. Inst. 9, 33, pp. $364-366$. (Ref. Rev. Appl. Myc. 37: 591, 1958).

(9) SPrague, R. 1956. Wheat snow mold in Eastern Washington 1955 to 1956. Pl. Dis. Rep. 40: 640642.

(10) $\rightarrow$ 1957. Wheat snow mold in eastern Washington in 1956-57. Ibid. 42: 279.

(11) WAGNER, F. 1957. Versuche zur Bekämpfung der Schneeschimmelauswinterung des Winterroggens in Höhenlagen. Bayerisches Landw. Jbuch, 34. Sonderheft 2: $30-36$. 
S E L OS T U S :

\title{
SYYSVILJOJEN TALVITUHOSIENTEN TORJUNTAKOKEISTA ERÄILLÄ KLOORI- NITROBENTSEENI- JA ORGAANISILLA ELOHOPEAVALMISTEILLA
}

\author{
E. A. Jamalainen
}

Kasvitautien tutkimuslaitos, Tikkurila

Kasvitautien tutkimuslaitoksen syysviljakokeissa vv. $1955-1958$ oli päähuomio kohdistettu talvituhosienien aiheuttamien vahinkojen torjuntaan käsittelemällä oraat syystalvella erăillä kloorinitrobenseeni- ja org. elohopeavalmisteilla. Useimmat kokeet oli suoritettu Etelä-Suomessa.

Runsaslumisena talvena 1955-56 aiheuttivat talvituhosienet suuria vahinkoja peltokasveille kaikkialla Suomessa, myös etelä-osissa maata. Talvella 1956-57, jolloin lunta oli vähän ja maa oli syystalvella syväăn routaantunut, ei talvituhosienien aiheuttamia tuhoja esiintynyt syysviljoissa sanottavammin maan etelä-osissa. Keski- ja pohjois-Suomessa esiintyi talvituhosienivaurioita, mutta ne olivat tavallista vähäisemmät. Talvi 1957-58 oli normaali syysviljojen talvehtimiselle; lumisilla seuduilla ja runsaslumisissa kasvupaikoissa olivat talvituhosienien vauriot syysviljoilla melkoiset.

Talvehtimisvaurioiden aiheuttajina oli syysruiskokeissa etupäässä Fusarium nivale (Fr.) Ces., syysvehnäkokeissa sekä $F$, nivale että Typhula spp. sienet, $T$. itona Imai ja $T$. idahoensis Remsb.

Pentakloorinitrobentseeni (PCNB) ja org. elohopeavalmisteet, fenyylimerkuriasetaatti (PMA) ja fenyylimerkurisalisylaatti (PMS), vaikuttivat tehokkaasti sekä Fusarium - että Typhula-sieniin kokeissa, joissa oraiden käsittely oli suoritettu etelä-Suomen olosuhteissa marraskuussa. Vastaavasti aikaisemmin lokakuussa suoritettujen käsittelyjen teho jäi heikommaksi marraskuun käsittelyihin verrattuna.

PCNB-valmisteilla sekä PMA- ja PMS-elohopeavalmisteilla marraskuussa suoritettujen oraiden käsittelyn ansiosta johtuvat sadonlisäykset olivat koetalvina $1955-56$ ja $1957-58$, jolloin talvituhosieniä esiintyi runsaasti, varsin huomattavat: syysrukiilla (7 koetta), vaihdellen $12-122 \%$, syysvehnällä (4 koetta), vaihdellen $31-735 \%$, ja syysohralla (yksi koe) $124 \%$. V. 1956-58 kokeissa ei talvituhosienien puuttuessa oraiden käsittelyllä saatu etelä-Suomessa sadonlisäyksiä.

Elohopeavalmisteet PMA ja PMS olivat tehokkaampia syysviljojen talvituhosieniin kuin PCNBvalmisteet.

Zineb- ja heksakloorinitrobentseeni- (HCNB-) valmisteiden teho syysviljojen talvituhosieniin oli huomattavasti heikompi kuin PCNB- ja org. elohopeavalmisteiden.

PCNB-valmisteissa oli vaikuttavan aineen määrä useimmissa kokeissa $5 \mathrm{~kg}$ halle. Kokeiltavana olleessa kahdessa PMA-valmisteessa oli vaikuttavan aineen määrä 125 ja $425 \mathrm{~g}$ halle, vastaavat $\mathrm{Hg}$ mäărăt 75 ja $212.5 \mathrm{~g}$ halle, sekä kahdessa PMS-valmisteessa 235 ja $470 \mathrm{~g}$ halle, vastaavat $\mathrm{Hg}$-määrät $110.5 \mathrm{~g}$ ja $221 \mathrm{~g}$ halle.

Syysrukiin peittauskokeessa v. $1955-56$ tehosi org. elohopeavalmisteiden ohella myös tiramvalmiste hyvin Fusarium-homeeseen.

Kylvösiemenen peittauskokeissa on Suomessa saatu varsinkin syysrukiilla huomattavia sadonlisäyksiä org. elohopeavalmisteilla, siemenen ollessa normaalisti itävää eikä lumihomesienen saastuttamaa. Tämä osoittaa, että siemenen mukana maahan tuleva vähäinen măărä elohopeaa vaikuttaa talven aikana talvituhosieniä torjuvasti. 